\title{
The quest for hermeneutics of appropriation as a thematic approach for critical biblical interpretation
}

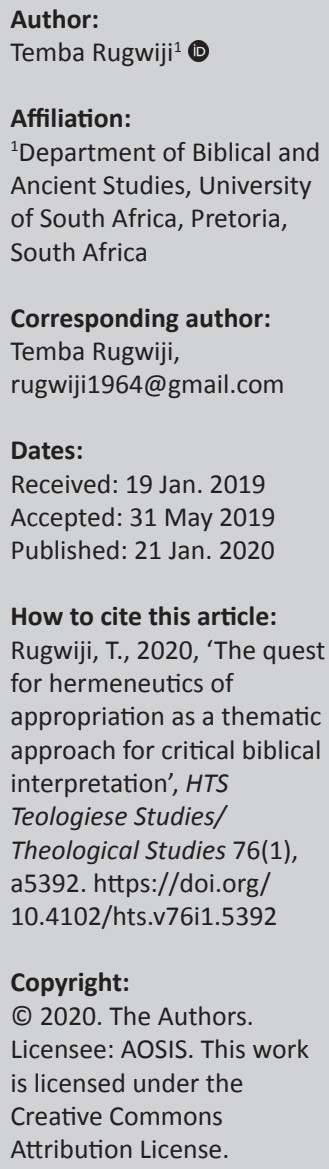

This study attempts to promulgate a method called 'hermeneutics of appropriation' as a thematic approach of a scientific research. 'Hermeneutics' is not the same as 'appropriation'; hermeneutics refers to a science of interpretation, whereas appropriation depicts an idea of adoption. Hermeneutics of appropriation employs themes (hence, thematic analysis) as opposed to contextual biblical hermeneutics that focuses largely on contemporary interpretation of biblical narratives. Thus, adopting the phrase 'hermeneutics of appropriation' presents the idea of a scientific interpretation of a theme that is applied in a differing context from which it originated. The present study aims at highlighting some dynamics that illustrate contextual biblical interpretation as a biased approach. Having presented such dynamics, the study will then suggest the employment of hermeneutics of appropriation in which relevant themes from the biblical text are utilised in a hermeneutical discourse. A dialogue with various previous contributions that conferred on contextual biblical hermeneutics will illuminate the above notion. With regard to hermeneutics of appropriation, representative examples of themes from the Judean postexilic context to be appropriated in the Zimbabwean postcolonial discourse comprises of two aspects: (1) geopolitical and socioeconomic crises and (2) Nehemiah's social justice reforms. The latter consists of five subthemes: public hearing to rebuke the leadership, condemnation of usury, payment of tax, return of personal property to the owner and food donation to the needy.

Keywords: Hermeneutics of appropriation; Research; Thematic analysis contextual biblical hermeneutics; Ancient biblical texts; Old Testament; Judean postexilic context; Social justice reforms.

\section{Introduction}

Hermeneutics of appropriation (HA) ${ }^{1}$ as a thematic analysis (TA) concerns society and their practices of living and worldviews (Rugwiji 2013:6). Human beings borrow ideas and practices from other cultures; it happens everywhere, both ancient and modern. However, most previous contributions have explored on contextual biblical hermeneutics $(\mathrm{CBH})$, but the present study appropriates themes from the ancient biblical text in a contemporary situation. By adopting this approach, the researcher attempts to avoid presenting the ancient biblical text as a historical reality in a modern-day life experience. The traditional approach of adopting $\mathrm{CBH}$ is complex when one attempts to interpret the Bible in a diverse context where numerous views are critically opposed to regarding the ancient biblical text as a 'road map' by which modern societies should live (Rugwiji 2013:6). Admittedly, appropriation of the ancient biblical text for today is paramount because ancient biblical narratives deal with human beings and their relationships among themselves as well as their responses to particularities of everyday life that are common both in the ancient past and in today's modern world (Rugwiji 2013:6). In addition, some communication that derives from practices as depicted by ancient biblical themes may inform how modern societies can conduct themselves and perhaps improve their lifestyle for the better (Rugwiji 2013:6).

In a previous work, Rugwiji (2013) employed HA to analyse biblical themes such as the socioeconomic and geopolitical situations in postexilic Judah, which he critically appropriated in the postindependence Zimbabwean situation. In another contribution, Rugwiji (2008) appropriated the exodus liberation motif in the Zimbabwean situation. Rugwiji deliberately avoided a historicalcritical approach (see Upkong 2000:17; West 1991:131) of the postexilic narratives in preference for the literary-rhetorical approach because the original intention of explicating postexilic narratives 1.This study derives largely from the author's previous research.

Note: Some of the writing and research of this article is based on work previously published by the author. 
was streamlined along the literary theme. However, historical criticism is often criticised for confronting the text to the extent that it no longer has a positive message for the presentday world (Scheffler 2007:772). Thus, Spangenberg (2011) remarked that historical criticism should not be the dominant discourse, but one among others. Nevertheless, Rugwiji does not entirely critique historical criticism. Instead, historical criticism is regarded as a necessary approach in biblical interpretation that enlightens the readership that the ancient biblical world and biblical Israel should seriously be considered as the context and the audience out of which the biblical narratives emerged (2013:20).

The present study draws some inspiration from the studies by Paul Ricoeur, Richard Kearney, Ruby S. Suazo and Jonathan Roberge, which, in my view, succeeded in illuminating hermeneutics as a method of interpreting ancient biblical narratives. However, the present research has adopted a 'thematic' study of the biblical text but still maintained ideas enshrined in hermeneutics. The thematic approach adopted for this essay is a deliberate attempt to deviate from a traditional approach of appropriating (contextualising) ancient biblical narratives in a contemporary context. A list of research projects that have attempted to contextualise (or appropriate) biblical narratives in postbiblical context is inexhaustible. Although most African biblical scholars argue for the presence of an African within the biblical text (e.g., Adamo 1989:17-25; 2001:46-47; Dada 2010:161), HA differs from the above approaches by way of employing TA to discuss identified themes as depicted in the ancient biblical text. Hence, scholars assert that a point of convergence $^{2}$ exists between HA and TA. The study by Roberge (2008) has also contributed immensely in both the formulation and development of ideas included in the present study. Roberge argues that critical hermeneutics refers to the conjunction and articulation of three theories: a theory of meaning, a theory of action and a theory of experience. This discourse commences by defining hermeneutics and hermeneutic analysis.

\section{Definition of Hermeneutics and Hermeneutic Analysis}

Terry defines hermeneutics as 'the speculative science of biblical interpretation' (1983:20). Richard Kearney describes it as 'hermeneutics of action' (1996:1). According to Kearney (1996:1), hermeneutics of action is an intentional method of interpretation aimed at unmasking the underlying meanings within the text for modern readers that traditional methods such as historical criticism, redaction criticism, among other 'criticisms' would not account for. Interpretation is the 'work of thought that consists in deciphering the hidden meaning in the apparent meaning, in unfolding the levels of meaning implied in the literal meaning' (Ricoeur 1974:60). For Suazo (2008:114), appropriation connotes understanding at and through distance. Suazo agrees with Ricoeur (1974), who wrote that: 'To appropriate is to make what was alien become one's own ...' Suazo (2008) further writes that:

Because the meaning of the text is autonomous, it escapes from the psychological intention of the writer. Its truth value is now independent from the writer's original intention. The sense as envisioned by the author may now have a reference different from the situation of the reader. (p. 111)

However, Rugwiji (2013) maintains that:

Although some scholars (e.g., Paul Ricoeur, Richard Kearney, RS Suazo, among others), have succeeded in proposing the employment of HA in interpreting ancient biblical narratives, this study deviates from such an approach. Instead, the present research has adopted a thematic study of the biblical text while still maintaining ideas enshrined in HA. (p. 16)

Meanwhile, Boland (1985) maintains that hermeneutic analysis can be used to understand the organisation or the institution as a whole. Boland (1985) agrees that hermeneutic analysis focuses on a wider research context and takes into account the entire background of the research during data collection. Kelebogile Thomas Resane remarked that: 'Biblical hermeneutics is the art or technique of interpreting the biblical text in order to understand its original context and then find its contemporary meaning' (2018:1). Contrary to Resane's view, the more 'universal' definition of hermeneutics is that it is a science or technique of interpretation. It is repeatedly expressed in both modern dictionaries and theological discourses that hermeneutics is used as a method of interpretation particularly of the biblical text. The definition that hermeneutics is a 'move from what the text meant to its original audience to what it means to Africans in their context' as depicted in other contributions is not only a misrepresentation of facts, but also conveys a different meaning from the 'universally acceptable' meaning of the term 'hermeneutics'. In my view, Resane's definition (among others) is not only inaccurate, but also demonstrates a bias towards 'squeezing' ${ }^{3}$ the biblical text in order to justify an interpretation in the African context. Hence, Eben Scheffler noted that "as we consciously attempt to "appropriate" the text for today, we are confronted with the "past-ness" of the text we are dealing with' (2013:13). Having discussed hermeneutics and hermeneutic analysis, this treatise now engages contributions in $\mathrm{CBH}$.

\section{Engagement with Contributions in contextual biblical hermeneutics}

$\mathrm{CBH}$ is a traditional method of biblical interpretation common among most biblical commentators. Various contributors have employed $\mathrm{CBH}$ in articulating their arguments in their respective discourses, although different terminologies have been used to describe the method, such as: contextualisation, enculturation, black theology and feminist theology, among others. ${ }^{4}$ Others prefer to call the method comparative study/comparative hermeneutics (see Farnen 1994; Launderville 1989). It appears a point of 3.For this view, see for example, Meyer 2015:1-7.

4. Examples of contributions on HA are discussed in this study. 
convergence exists between $\mathrm{HA}$ and $\mathrm{CBH}$ that Dada (2010:160-174) describes as a 'deliberate attempt to introduce African situational concepts and ideas into reading the biblical text'. Dada's explanation depicts the method of biblical interpretation largely preferred by many African scholars. However, the divergence lies in that HA conveys the 'other' possible meaning by utilising relevant themes from the biblical text. Some examples of contributions in CBH will suffice.

In his MA thesis entitled: The Bible and literature: A case of biblical influence in some Shona novels (2003), Jacob Mapara's contribution remains one of the remarkable examples of $\mathrm{CBH}$ that focussed particularly on Zimbabwe. Mapara (2003:20) maintains that among the Shona, folktales and songs were told and sung to teach people issues of high moral values. Mapara further explains that some Zimbabwean Shona novelists were able to adopt and adapt Bible stories and use them to teach moral issues to their people. These Bible stories include the story of Moses who had to leave Egypt for Median from where he received a message from Yahweh for the liberation of the Israelites from the Egyptian bondage (Ex 2:15-25). Mapara likened Israel's bondage to colonial policies of Rhodesia (now Zimbabwe) that oppressed the majority of black people.

In the Gospel according to the ghetto (1990), Canaan Banana elucidates the exodus tradition of an oppressed people (the Israelites) under an imperial authority (the pharaohs) and how they were liberated by God. Moses was used by God as a vessel through which Israel's deliverance could be realised. In spite of him being brought up in Egyptian lifestyle, Moses did not forget that he was an Israelite. According to Banana, this is taken as a clear indication that God does validate liberating violence. As Rugwiji (2008:109) observes, Banana sees the war of liberation in Rhodesia (now Zimbabwe) as God's way of intervening to secure and ensure black people's dignity, freedom, self-determination and happiness.

In my view, Mapara's and Banana's comparisons ('likening') of the biblical stories (especially the exodus tradition concerning the slavery and the 'going out' of the Israelites from the Egyptian bondage) to Zimbabwe's narratives about colonialism, the nationalist liberation and the liberation in 1980 contradict the thrust of the present research on HA. Mapara's and Banana's approaches tend to promote a bias towards 'forcing' the text to say what it did not mean in its ancient Israelite context. Both Mapara's position and Banana's stance are among various contributions that have used the 'exodus liberation narrative as a liberation text' (Scheffler 2013:3). The list includes: Gustavo Gutierrez, James Cone, Elelwani Farisani, David Tuesday Adamo, among numerous others.

Gustavo Gutierrez also presents the exodus motif in a direct way in comparison with the contemporary situation. Gutierrez (1973:155) remarks that the creative act of God is linked and almost identical with the act that freed Israel from slavery in Egypt. Creation and liberation from Egyptian bondage are but one salvific act. He further affirms that the God of the exodus is the God of history and of political liberation than $\mathrm{He}$ is the God of nature (1973:157). In Gutierrez' assertion, the exodus motif forms the basis for a theological liberation engagement and establishment of revolutionary activism in Latin America. It appears that literature and academic writing in Latin America were influenced, to a large extent, by reading the exodus liberation tradition. Hence, Gutierrez affirms that in Latin America to be church today means to take up a clear position regarding both the present state of social injustice and the revolutionary process that is attempting to abolish that injustice and build a more human order (Gutierrez 1973:265). Gutierrez' ideology, in my view, contrasts hermeneutics appropriation in which relevant themes are appropriated in a contemporary situation. Gutierrez' ideology was followed up by another liberationist named Song (1979:568), who reiterated that the experience of the exodus does become alive and real for the black people of the United States. Bennet (1971:422) had previously reverberated that as the tale of sorrows of people awaiting deliverance, the black narrative has a message consistent with the biblical witness though not found in that witness. Jürgen Moltmann, who is also famous for appropriating biblical narratives in the contemporary context, also wrote that Yahweh is the God who leads His people out of the house of bondage (1968:53). James Cone is one of the outstanding proponents of the exodus liberation tradition. Cone, who is also enlisted among the supporters of Moltmann, opined that the election of Israel is inseparable from the event of the exodus (1990:2). Cone's (1985:64) spirituals, namely: 'Go down Moses', is typical of the exodus tradition, which he formulated for his contemporary readership.

Elelwani Farisani's contribution in $\mathrm{CBH}$ can also be noted. Farisani (2010:507) writes that apartheid ideology systematically oppressed and dehumanised black people. Farisani further affirms that black theology used the Bible as a weapon in the struggle of black people against apartheid ideology. Farisani remarks that the Bible should be the same tool that can be used to decolonise Africa in order to reclaim her identity. Farisani's stance followed up on the position taken by his predecessor, Gerald West, who had previously stated that if the Bible and biblical scholarship had been instruments of colonising cultures in the past, there is no reason why, in the present they cannot serve as instruments of liberation (West 1997:32-342). Farisani (2011:61-72) further laments that the church should not only look at the question of the relationship between God and the poor but also at the relationship of the God of the poor (the God of life) with the economic, political and social particularities of concretely oppressed people. Another scholar who, over the years, has developed some interest in African biblical hermeneutics is Knut Holter. Holter (2002) maintains that the African context and the biblical text should interpret each other. Holter (2002:88-89) states that comparative studies facilitate a 
parallel interpretation so that the two illuminate each other. Holter further explains that in African biblical hermeneutics, the biblical text is approached from a perspective where African comparative material is the major dialogue partner and traditional exegetical methodology is subordinated to this perspective (2002:88).

Similarly, Masenya (2004:3) has also widely contributed to the debate on $\mathrm{CBH}$, where she makes reference to 'theologies aimed at addressing the real needs of African people'. Masenya refers to the Bible being relevant to the politics, economy, family issues, liberation, etc., among modern African societies. Masenya (2010:728-751) draws an analogy from the family structures and units of Judah during the preexilic, exilic and postexilic periods respectively to the family structures and their economic survival in South Africa during and after apartheid. Masenya further observes that in both the (pre-exilic Israelite) postexilic Jewish community contexts and the African/Northern Sotho context, there was an expectation that parents, both in nuclear and extended families, would offer education to their children (including those who were not their blood children). Masenya also compares parent-child relationship in Proverbs 1:8-9; 6:20 to the Northern Sotho South African context, which, in her view, 'share a similar content even as they reflect some points of resemblance with regard to the worldview that they display on parental instruction'(Masenya 2010:749).

Maré's argument that 'the experience of exile is not confined to the pages of the Bible dealing with the Babylonian exile' and that 'exile happens in our midst' (Maré 2010:116-128) also depicts a thrust towards CBH. Maré (2010:117) remarks that the loss of the reliable and known world results in many people living in a strange and unfamiliar situation that does not seem like home, but creates a deep sense of being in exile. Adamo (2010:15) maintains that the forceful removal of Africans from their continent to various foreign countries in the west and their accompanied suffering can be compared with that of the exile of 597 and 598 and 586 and 587. Adamo (2010:22) also explains the similarities that exist between Yahweh punishing Israel for sinning by allowing the invasion and loss of the land by Africans to foreigners because they sinned against the gods. Upkong (1994:3-15) talks of enculturation hermeneutics in which he proposes a holistic approach to culture whereby both the secular and religious aspects of culture are seen to be interconnected and as having implications on the other, and that the Bible is read within the religious as well as the economic, social and political contexts of Africa.

Upkong (2000:3) observes that since the 1990s a decidedly proactive stance is leading to the development of contextual Bible studies and enculturation approaches, which recognise the importance of the ordinary reader and make the African context the explicit subject of biblical interpretation. The importance of the ordinary reader will gradually come to the fore because academic reading of the Bible in Africa cannot continue to ignore the concerns and perspectives of the ordinary reader. Because African biblical scholarship focuses on the community that receives the text, any continued ignoring of the ordinary readers will lead to sterile scholarship (Upkong 2000:18). Desmond Tutu presents himself as a protagonist of CBH. Tutu (1978:336) noted that no longer then shall we have from the Bible answers to questions not asked by Africans.

Elsewhere, individuals or a group of people would appeal to the Bible (or the exodus tradition) as a source of motivation for either conformist politics or some form of activism against perceived injustice. For example, the Great Trek by the Dutch of South Africa (also known as 'Afrikaners') was regarded as a type of an 'exodus' (Rugwiji 2008:72). Fisher (1969:63) remarked that the Great Trek - during which more than 10000 men, women and children (nearly a quarter of the European population of the Cape Colony) left its borders for good is regarded today as the most significant event in the history of the Afrikaners. The perspective of the Afrikaners was that the Great Trek of the 18th century was a kind of exodus in which the Dutch felt they needed to escape British rule because the latter had ill-treated them just as the pharaohs of ancient Egypt had held the Israelites in bondage (Fisher 1969:63). The list of contributions on $\mathrm{CBH}$ is endless.

This essay has illustrated by discussing various hermeneutical contributions as examples in which TA has neither been mentioned nor employed as an approach. This study therefore submits to the readership that as much as $\mathrm{CBH}$ remains the core of biblical interpretation and that chosen biblical narratives are 'uprooted and transplanted' in a particular context, the original and intended meaning is blemished. Ancient biblical themes can apply in every context but ancient biblical contexts don't. One would therefore suggest that $\mathrm{CBH}$ be employed responsibly, bearing in mind Eben Scheffler's observation that: ' ... those who study history for the sake of wisdom should also guard against interpreting it in terms of the lessons they want to learn' (2001:13). As the focus of the present research entails, one of the ways to avoid a bias towards $\mathrm{CBH}$ is to adopt an approach broadly perceived as HA that utilises TA, which is explained in the upcoming section.

\section{Thematic analysis}

As Nowell et al (2017:1) observe, TA is a relevant qualitative research method, yet little has been written to guide researchers on how to conduct a rigorous TA. Ibrahim (2012:40) defines TA as a type of qualitative analysis that is used to analyse classifications and present themes that relate to data. Hence, Boyatzis (1998) concurs that TA illustrates the data in great detail and deals with diverse subjects via interpretations. Thus, Marks and Yardley (2004) affirm that TA gives the opportunity to understand the potential of any issue more widely. TA is considered the most appropriate for any study that seeks to discover using interpretations (Ibrahim 2012:40). It allows the researcher to associate 
an analysis of the frequency of a theme with one of the whole content (Ibrahim 2012:40). TA provides the opportunity for researchers to move beyond calculating unambiguous words or statements or expressing the ideas (Ibrahim 2012:42). Javadi and Zarea (2016:34), who also acknowledged a position taken by Guest and Namey (2012), could not have defined it better by stating that TA is one of the most common forms of analysis in qualitative research. Javadi and Zarea (2016:34) reaffirmed that TA is an approach for extraction of meanings and concepts from data and includes pinpointing, examining and recording patterns or themes. Braun and Clarke (2006:8-10) remarked that Ground Theory is very similar to TA in terms of procedures for coding themes from data. In this study, TA is considered as consisting of a complementary character of HA, which is in the next section.

\section{The Function of Hermeneutics of Appropriation}

HA employed in this study is an attempt to engage the ancient biblical text about the postexilic Judean community in order to explore geopolitical and socioeconomic themes highlighted previously in this conversation. In a previous contribution, Rugwiji (2014) demonstrated that Old Testament scholarship was criticised for being unable to deal with contemporary issues affecting our modern societies today, such as political power, socioeconomic situations, justice, poverty, the environment, health, rape, murder and others. As an example, themes from the postexilic Judean society have been identified for an appropriation in the Zimbabwean situation. The study attempts to demonstrate that 'comparison' or 'contextualisation' of the biblical narratives in the contemporary world is not only biased but also flawed. The Bible is an ancient text and therefore cannot be appropriated in a contemporary context in a straightforward way; biblical themes can. For example, one would recognise the approach of an interpreter who comments on biblical themes of rape and murder to warn the readership to guard against committing such offenses. In a later discussion about the restored postexilic Judean society, this study illustrates how HA can utilise biblical themes for a contemporary context.

The freedom and return of the Jewish deportees came as result of the defeat and collapse of the Babylonian kingdom by the Persian general Ugbaru and the ascension onto the throne of Cyrus, the Persian (Spangenberg 2006:168). The Persians, an Indo-European people whose origins and centre of power lay in the territory north and east of the Fertile Crescent, quickly established the most comprehensive Near Eastern empire that existed until 539 BCE (Miller \& Hayes 1986:437-475). Under the Persian Empire, the Jews continued to strive towards maintaining their religious and national identities. For a while, the Judeans seemed to have settled (Spangenberg 2006:199-236). However, their independence was once again threatened by Alexander the Great's conquering spirit over the world through a policy of Hellenisation (Scheffler 2001), which established the benefits of Greek civilisation to those considered as backward peoples (Whittaker 1984:3). To say the least, from the Judean perspective, there were no real benefits to write home about. The Maccabean resistance or revolt is interpreted by some to be a reaction against a 'religious suppression' (Grabbe 1992:267-268). Still, among the Judeans themselves, there was also conflict of a religious, class and materialistic nature (Smith 1996:537-556). This multiplicity of crises, as explained by both Grabbe and Smith, among others, portrays that freedom was far from being realised within the postexilic Judean community. Hence, Berlin (2005:65) was right to state that exile does not necessarily mean living outside of the former kingdom of Judah. Rugwiji (2013:26) concurs with Berlin's contestation that although the Judean exiles finally returned to Judah, they continued to experience an 'exile' through oppression and enslavement exerted by their own Jewish leaders back at home, which caused 'men and their wives to raise a great outcry against their Jewish brothers' (Neh 5:1). Rugwiji (2013) maintains that:

The Old Testament, particularly the postexilic literature (e.g., Chronicles, Ezra, Nehemiah, Haggai, Zechariah, and others) portrays power play at work within the Judean community, just as power affects every spectrum of life among postbiblical societies today. (p. 26)

The above theme of 'a promise that was never fulfilled' / 'a expectation that was never realised' emerging particularly from the postexilic Judean community draws this study to investigate geopolitical and socioeconomic challenges in our postbiblical world as human predicaments that occur everywhere, especially among societies in which political power predilection precipitates poverty. Thus, Strydom and Wessels (2000) remarked that:

We all live in societies where we are very mindful of the important role power plays in the course of our daily lives. Power is daily exercised in governmental and all other social structures. Power has many faces, but to deny its existence is to deny the reality of life. (p. 11)

Strydom and Wessels' assertion complements Rugwiji's (2013:26) contestation that critical Old Testament scholarship should interrogate themes such as: politics, power, democracy, economy, poverty and suffering among societies. Similarly, Goldingay (2003) supports the above argument by postulating that:

In principle I am not interested in the Old Testament as a merely theoretical discipline. I am interested in it because I have found that the Old Testament has a capacity to speak with illumination and power to the lives of communities and individuals. Yet, I also believe it has been ignored and/or emasculated and I want to see it let loose in the world of theology, in the church and in the world. (p. 18)

Norman K. Gottwald's remarks are also enriching on both the political and economic themes within the postexilic community in Yehud. Gottwald (1985:375) affirms that the leaders of the Judean society were responsible for the deterioration of the old tribal order of communal equity. Both people and property were violated by political leaders in 
enriching themselves and strengthening their positions of power. Shaw (1993:109) concurs with Gottwald's point of view by describing the practice as 'abuse of power'. For Warmback (2008:166) the themes of poverty eradication and respect for the integrity of the natural environment take centre stage. Hence, Warmback (2008:167) argues that he is interested in a theology that takes seriously the environment and particularities of everyday life among societies. In my view, the main task of the biblical interpreter is an attempt to make the text 'speak' clearer for the ordinary reader, that is, the environment as Warmback correctly puts it. The Judeans were liberated and reunited with their fellow Jews who had remained in Judea. However, tension arose between the returnees and the remnants. This tension almost halted development in Judah (Rugwiji 2013:29).

When Emmanuel Usue (2007) appropriates the Ezra-Nehemiah themes in the contexts of the Nigerian and South African peoples today, he rightly examines the pitfalls associated with leadership and power. Usue's appropriation of themes in Ezra-Nehemiah for both the Nigerian and South African contexts is quite revealing. Usue (2007:831) observes that the paradox of restoration and desperation in Ezra and Nehemiah seems to echo or play out in Nigeria and South Africa as well. Usue further remarks that when African nations began to shelve away the shackles of colonialism, apartheid and military regimes, they turned to democracy hoping for a united, progressive and secured Africa, which, according to Usue, is not the case. Usue's (2007) argument is articulated more clearly in this statement:

The dreams about what freedom and democracy would offer are becoming a wishful thinking, given the spate of crime, wars, military coups, corruption and bad political and economic policies adopted and practiced by these nations. As a result, the era of freedom and democracy has impoverished Africans in essence rather than enhance their living conditions. (p. 831)

Usue's contention in appropriating the Judean postexilic themes in Ezra-Nehemiah for the Nigerian and South African contexts is conceived and derives from the postcolonial and post-apartheid experiences in Nigeria and South Africa, respectively.

\section{Themes to be appropriated in the Zimbabwe Context}

Usue's (2007) use of TA in the previous discussion correctly situates the present study on HA with a special focus on the Zimbabwean context. African countries emerging from decades of colonial subjugation or ethnic conflict have rekindled enslavement and oppression that have been criticised for exacerbating poverty on the majority of ordinary people (Rugwiji 2013:31). This discourse delves on appropriating the following two collective themes as representative examples from the Judean postexilic situation in the Zimbabwean context: (1) geopolitical and socioeconomic challenges and (2) Nehemiah's social justice reforms. The latter comprises the following five subthemes: public hearing to rebuke the leadership, condemnation of usury, payment of tax, return of personal property to the owner and donation of food to the needy.

\section{Geopolitical and socioeconomic challenges}

In postindependence Zimbabwe, geopolitical and socioeconomic challenges devastating the country have notoriously become known as the Zimbabwean crises (Chitando 2010:210; Maposa, Sibanda \& Makahamadze 2011:250; Rugwiji 2017:16). Hence, Zimudzi (2012:508) remarked that the Zimbabwean crisis (which became noticeable from 2000 and whose hallmarks have included collapse, widespread human rights violations and disputed) has continued to be the subject of numerous academic and nonacademic publications. Zimudzi (2012:508) further laments that it was Robert Mugabe's policies of political survival, characterised by disregard for political rights and economic welfare of fellow Zimbabweans, that predictably led to the economic and political ruin the country has experienced since 2000 to date. Under Mugabe's leadership, postindependence Zimbabwe has witnessed numerous unjust practices such as retaliatory reactions and influences of revenge for the 'sins' and experiences of the colonial past, particularly against the so-called 'beneficiaries' of colonialism (Rugwiji 2013:32).

Mugabe's revolutionary machinery was deployed to torture, subject, marginalise, oppress and exploit his own black people believed to be the enemies of the state, suspected to be having Western connections and/or allies (Rugwiji 2017:16). The guerrilla veterans of the Zimbabwean liberation war played a prominent role in intimidating members of the opposition, the Movement for Democratic Change (MDC) and in spearheading the invasions that drove out white commercial farmers from the land and led to the chaotic 'fasttrack' land-distribution reform exercise, popularly known as the Third Chimurenga (Kriger 2003:407; Rugwiji 2017:16). This marked the beginning of almost a decade (2000-2008) of economic turmoil, which devastated the people of Zimbabwe (Rugwiji 2013:32). To date (08 January 2019), the economy of Zimbabwe is once again at its worst and the path to recovery is not imaginable any time soon. One may pose the question: What factor(s) caused the economic downturn in Zimbabwe? The answer is: poor leadership. Thus, Compagnon (2011) once remarked that the current Zimbabwean crisis was a predictable and logical consequence of the character and policies of Robert Mugabe since independence. Compagnon's observation confirms Rugwiji's (2008:137) argument that Mugabe's character was violent and militant from the beginning. Mugabe had always believed that war and armed struggle would bring freedom to the Zimbabwean people. As the war of liberation in Zimbabwe intensified, other nationalists such as Joshua Nkomo, among others, were willing to come to terms with Ian Smith (Rugwiji 2013:33). Mugabe was opposed to Nkomo's proposal as the former believed in the armed struggle as an essential part of the process of establishing a new society (Meredith 2008:2). 
Thus, Rugwiji's (2013:33) argument that: 'Many people believe that Mugabe's attitude and his practice of dictatorship and human rights violations were a time bomb waiting to explode' is suggestive of similar contestations raised by both Compagnon and Meredith.

\section{Nehemiah's social justice reforms (North 1969)}

The book of Nehemiah posits that Judean men and their wives raised a great outcry against their Jewish brothers (Neh 5:1). Thus, the story in Nehemiah 5 reveals an internal crisis within the returned community itself (cf. Usue 2007:841). The Bible expresses the view that the word of the oppressed is the 'cry' and that Yahweh always responded when the cry of his people reached him (Ex 3:7-10; 6:5). The difference between the cry by this postexilic community and that of their ancestors in Egypt is that the Judeans protested by going to the streets to express their grievances against their Jewish leaders. As in Psalm 137 that depicts the exiles' 'cry' for vengeance, the outcry in Nehemiah 5:1 is a protest for justice (Strawn 2009:348). The Judean postexilic community of 'men and women and their children' (Neh 5:1) was exposed to extreme poverty owing to various circumstances, especially that of lending money and charging interest, referred to by Nehemiah as usury. Nehemiah 5:1 expresses the view that the suffering did not spare the male folk, hence their 'outcry' together with women as a result of the oppression. However, the wives were involved in the protest against the Jewish leadership for the household economy and the welfare of their children (North 1969:436). What worsened the feelings of frustration and anger of this community is that their plight was exacerbated by their own Jewish governors, their own Jewish brothers (Neh 5:1). Previously, the Judeans were under captivity in Babylonia and they were now restored back to Judah. But their situation had worsened. Apart from their own Judean governors who treated them ruthlessly, they were also required by the Persian authorities to pay taxes to the government. Was Isaiah not prophesying Yahweh's oracles of peace and justice after the exile (Is 14:7; 55:12; 57:19)? On the contrary, peace and tranquility were not to be found in Yehud. This postexilic community could no longer remain passive under the experiences of lack and deprivation. They decided to confront the 'rulers' in an attempt to instil sanity, so that the Governors would attend to the plight of the oppressed. So, the community of males and females appeared before the Jewish governors and appealed for food supplies. They said: 'We and our sons and daughters are numerous; in order for us to eat and stay alive, we must get grain' (Neh 5:2). The community comprised many people as expressed by the word numerous. During the previous years when they could not pay tax owing to a lack of yield from the land because of drought, they ended up mortgaging their fields, vineyards and homes to pay tax and to get grain from the government (verse 3-4). Obviously the leadership and their families were not affected by the drought as expressed in verse 5; the ordinary folks, on the other hand, had to 'subject their sons and daughters to slavery'. So, these people had literally nothing left of their own, which made Nehemiah 'very angry' (5:6). Thus, Nehemiah introduced five reforms: (1) public hearing to rebuke the leadership (5:7), (2) condemnation of usury, (3) payment of tax, (4) return of personal property to the owner (5:11) and (5) donation of food to the poor each day (5:17-18):

1. Public hearing to rebuke the leadership. Nehemiah chose to listen to the concerns of 'demonstrators' as these were serious, given that parents and their children went to the streets, crying loudly, as expressed by '... raised a great outcry' (5:1). After hearing about their hardships, Nehemiah became angry towards the Jewish governors for exploiting the people (5:6). Nehemiah's disapproval of the Jewish leadership's actions of usury and greed led him to call for a public hearing with the leadership (5:7) in which he rebuked them for perpetuating a cycle of oppression with 'our Jewish brothers' whom 'we have bought back who were sold to the Gentiles'. By 'Gentiles', Nehemiah was probably referring to the Babylonians/ Persians. So, Nehemiah stood out as a prophetic voice to challenge the leadership. The nobles and officials accepted the challenge and agreed to act accordingly (5:12). In the Zimbabwean context, many people are still struggling for survival owing to various macro-and microeconomic challenges. One thing that the Zimbabwean people will avoid doing is to go on the streets in protest against the leadership. As noted by Rugwiji (2012:160) that in view of the Public Order and Security Act (POSA) it is illegal for people to form a group. For example, on 01 August 2018, during a protest march in the capital Harare over the outcome of the election results, six people were reportedly shot dead by armed soldiers (Mustaka 2018). One of the victims was reported to be a woman who was rushing to her car after closing her business premises (Mustaka 2018). The Zimbabwean government is notorious for intolerance towards the protesting public expressing their grievances when service delivery is neglected; the political leadership will always interpret a legitimate protest as a rebellion and will respond too harshly by deploying either the police or the army (Rugwiji 2012:160). Usually, a few prominent individuals among protesters are whisked away by the law enforcement agencies for inciting the masses to go to the streets in demonstration. Although there is a need for some leaders to come to their senses by challenging others to follow their example, the Zimbabwean government has been extremely resistant to accept challenge. However, there is a need for a selfless sacrifice for someone to take a bold stance like Nehemiah and rebuke the leadership for wrongdoing and for oppressing the people.

2. Condemnation of usury. The nobles and officials were challenged to stop usury (Neh 5:10), a kind of corruption that forced the borrower to return a loan with huge interest. Buckley (2000:2) observes that usury literary means 'a bite' owing to its painfulness to the debtor (Ex 22:25; Dt 23:19, 20), which in Leviticus 25:36-37 is referred to as an 'increase'. Both meanings carry the idea that the borrowers would repay more than they had 
originally borrowed from the lender. The poverty-stricken Judeans would be left with nothing to give to their 'wives and children' after repaying the loan plus interest. People had borrowed money 'to pay the king's tax on our fields' (Neh 5:4). However, in both the books of Exodus and Leviticus the practice of lending money and charging interest was prohibited (Ex 22:25; Lv 25:36). For example, in Zimbabwe, many people borrow money from individual lenders in an informal (and also illegal) system known as chimbadzo (same as usury). In this practice, the borrower will pay say $50 \%$ of the amount borrowed in interest. It does not matter whether the money is borrowed half-way before month-end. Sometimes people have formed a syndicate of lenders who have come together to 'circulate' their money in a lending scam. Only one person in the group is actually known by clients as the lender. There is no law that protects both the lender and the borrower; the operation is conducted on the basis of mutual understanding. However, owing to financial crunch, the borrowers end up in a borrowing culture; soon after repaying the loan, they borrow again. The law enforcement agencies in Zimbabwe do not seem to realise the gravity of this 'gambling', and there does not seem to exist a law that regulates this kind of 'business'. However, the business of lending at interest is officially known to be run by established financial institutions although the interest rate charged by the banks is lower than that charged by privately owned lending houses.

3. Payment of tax. Turning once more to the Judean communities, they were 'ripped off' through payment of tax. Ezra 4:20 reads, 'Jerusalem has had powerful kings ruling over the whole Trans-Euphrates, and taxes, tribute and duty were paid to them'. However, when the temple reconstruction project was completed and the temple dedicated, some Judean citizens were exempted from paying tax, tribute or duty, such as 'priests, Levites, singers, gatekeepers, temple servants and other workers at this house of God' (Ezr 7:24). The above situation in Yehud draws this discussion to explore the subject of paying tax in Zimbabwe. The Zimbabwean government - like many other governments in the world - largely survives on tax paid by businesses, employees and individual entrepreneurs, among other sources of revenue collection (Rugwiji 2013:168). Rugwiji maintains that although it is the duty of every citizen to pay tax in order for government to run national programmes and social services, the grim reality is that the abuse of tax money is ever increasing.

4. Return of personal property to the owner. Land and property issues were at stake among postexilic Judean societies. Their fields, vineyards and homes (Neh 5:3) were 'invaded' and seized by those in positions of power because they could not repay their loans, and their children were enslaved (5:5). The biblical text portrays the view that land, fields and vineyards were central to Israel and her relationship with Yahweh. However, Israel had to abide by the rules of the game: if the Israelites humbled themselves, prayed, sought God and turned away from their wicked ways, God would forgive them and heal their land (2 Chr 7:14); failure to obey Yahweh's command would result in losing the land (2 Chr 7:20), for example captivity in Babylonia. When they arrived in Judah, Ezra warned the Judeans not to be 'polluted by the corruption of the peoples of the land' (Ezr 9:11). We also read about vineyards and their significance in the biblical text. In 1 Kings 21 we read about the vineyard and the subsequent death of Naboth, the owner. Naboth's death followed his refusal to give his vineyard to Ahab saying: "The Lord forbids that I should give you the inheritance of my fathers' (21:3). The book of Proverbs provides that 'a noble wife who buys a field in order to plant a vineyard' (Pr 31:16). This implies that during biblical times people would buy a piece of land in order to plant some crops. One would also plant a vineyard on a hill, which was perceived to be fertile (Is 5). Judah is appreciated by Sennacherib, the king of Assyria, as 'a land of grain and new wine, a land of bread and vineyards' (Is 36:17).

Nehemiah 10:31 explains that on the Jewish calendar, every seventh year the Jews would not work the land and all debts would be cancelled. Nehemiah further expresses disappointment for seeing people working on the Sabbath by treading winepresses and bringing in grain and loading it on donkeys, together with wine, grapes, figs and all kinds of loads (Neh 13:15). This demonstrates that farm business was a daily activity in Yehud, undertaken even to the point of transgressing the commandment to keep the Sabbath holy.

Thus, the livelihood of the Jewish communities derived largely from subsistence farming; in the fields and vineyards, corn, fruit, grapes and vegetables were grown. The prophet Joel (Jl 1:11) talks of farmers who are desperate: 'Wail you vine growers; grieve for the wheat and the barley, because the harvest of the field is destroyed', an indication that the farmer's produce from the fields comprised barley, millet, wheat, wine, oil, and salt (Ezk 4:9; Ezr 6:9). Some of the vegetables included beans and cucumbers (Nm 11:5; Ezk 4:9), or melons, olives, figs, and grapes (Is 1:8; 17:6; Jr 24:1-3; Neh 13:15). Isaiah 55:1 mentions buying 'wine' and 'milk', implying that among them there were vinedressers and goat breeders who would then sell to others wine and milk and receive 'money'. The leaders in Nehemiah's time had vowed to bring to the storerooms in the temple foods such as: ground meal, grain, fruits of all trees, wine, oil and tithes of crops (Neh 10:37). Haggai's mentioning of 'You have planted much, but have harvested little' $(\mathrm{Hg} \mathrm{1:6)}$ is also a clear indication that the Judeans were an agrarian community. Grain and wine also appear in the book of Zechariah, who writes that: '... Grain will make the young men thrive, and new wine the young women' (Zch 9:17). The Judeans also bred animals on the farms, from which they would bring sacrifices and tithes to Yahweh (Ps 50); Malachi writes that Yahweh was upset by people who were stealing by giving Yahweh sacrifices of animals that were blind, crippled and disease-ridden (Ml 1:8). To a large extent, the Judeans survived on subsistence farming as indicated by terms such 
as 'fields' and 'vineyards' (Neh 5:3, 5), which were in turn taken as mortgages by those in power. Nehemiah might have been upset by the level of arrogance displayed by the leadership who refused to recognise the importance of people's collective production, both to the nation and to their own families. He demanded that the leaders return the fields, the vineyards and the homes to their original owners (5:11). To this end, Nehemiah also set up a task force that was headed by priests to make sure that 'nobles and officials take an oath to do what they promised' (5:12). Perhaps the oath was a kind of written agreement to that effect. In response, the leaders committed themselves to repay what they had taken from the poor in society. We also read that Nehemiah although he was a governor and all government resources, including land, were at his disposal - did not acquire a piece of land (5:14) because the generality of the population did not have land:

5. Donation of food to the poor each day. Nehemiah turned his homestead, or government house where he probably stayed, into a rendezvous where he fed 'a hundred and fifty Jews and officials ... as well as those who came to us from the surrounding nations' (5:17). The food that was prepared for him each day, Nehemiah gave to members of the community, included ox, sheep and poultry. Every 10 days Nehemiah had a ration of 'an abundant supply of wine of all kinds' (5:18). This portrays Nehemiah as a leader committed to alleviating poverty in the community. However, Nehemiah was the opposite of the nobles and officials among the Judeans. Nehemiah invited members of the community to come and eat at his homestead (5:17). Nehemiah also gave people food every day with a clear conscience, knowing that their 'demands were heavy' (5:18). Now that Nehemiah had rebuked the nobles and officials to stop usury and to return the vineyards and homes to the rightful owners (the poor peasant farmers), and perhaps follow Nehemiah's example of providing food, the deprived farm communities would begin looking into the future with hope.

The political leadership should lead by example by donating food to needy people, instead of leaving the exercise to non-governmental organisations (NGOs). Besides, those in power should not disrupt individuals or donor organisations that are committed to transforming the economy. Mashayamombe (2009) has reported of ZANU (PF) war veterans and youth militias in the Manicaland Province who vowed to disturb distribution of food aid if NGOs do the exercise without ZANU (PF) members present. Such trends of prohibiting NGOs to distribute food have been a feature during the past few years of political uncertainty in Zimbabwe. SAPA-DPA (2008:5) has reported of President Mugabe's government suspending the operation of Care International, the United States-based relief organisation, alleging involvement in 'political activity'. Such actions of disruptions are not only exacerbating starvation among communities, but are also detrimental to reversing the noble campaign of economic development and poverty reduction in the country. On the other hand, food corruption involving government or party leadership should be condemned and culprits should be punished. For example, one incident of corruption involved the leadership in ZANU (PF). Muchemwa (2009) revealed a ZANU (PF)-controlled food taskforce plundering thousands of tonnes of mealie-meal and maize in Bulawayo at a time when residents were going to bed hungry. Muchemwa has further reported that the majority of Zimbabweans cannot afford to buy mealie-meal because they have restricted access to foreign currency, leaving the corrupt ZANU (PF) members to benefit at the expense of many.

However, examples of charity received from the region are also worth mentioning. Our leadership ought to emulate what these others from outside are doing for the people of Zimbabwe. Foss (2009:6) reports about Jenny Des-Fountain of South Africa who, upon her 50th birthday requested food donations for her birthday, and, subsequently, sent the abundance of food to starving people in Zimbabwe. Meanwhile, the Zimbabwean leadership could follow the example of Nehemiah by paying school fees for learners who are struggling to pay fees owing to poverty. Some of these learners come from poor backgrounds, and some are orphans. It is not logical for government ministers to disregard 'pooling' their resources and donate aid to needy members of society. One minister could just forego one month's salary in order to donate the money or buy food to give to starving people (Rugwiji 2013:97, 116). One will be surprised by the difference such a gesture will make if only a small number of ministers commit themselves that way towards helping the poor. However, a beggar mentality should be discouraged as poverty-stricken communities develop a culture of often depending on aid. Communities should be urged to work hard as opposed to relying on well-wishers for their survival. Zimbabwe is on record for discouraging donor dependency, which is to be applauded. In contrast, the leadership in and of itself does not do anything to salvage the starvation situation in the country.

\section{Conclusion}

It was argued in the present study that hermeneutics is not the same as appropriation; hermeneutics is the science of interpretation, whereas appropriation is an adoption or borrowing. When one reads ancient biblical narratives, various themes emerge that are consistent with particularities of everyday life in a postcolonial or postbiblical context. The function of HA in this study was an attempt to demonstrate that by utilising a TA, one is safe from criticism against a 'straight-forward' appropriation of ancient biblical narratives in a contemporary context. It was explored that by employing $\mathrm{CBH}$, the interpreter faces the criticism of 'squeezing the text', hence 'forcing' it to fit into a contemporary postbiblical world. Such an approach has been criticised various by scholars. Representative examples of contributions on $\mathrm{CBH}$ were discussed in this essay. In the final analysis, HA was suggested as a technique in a biblical interpretation. 


\section{Acknowledgement \\ Competing interest}

The author declares that no competing interest exists.

\section{Author contributions}

I declare that I am the sole author of this research article.

\section{Ethical consideration}

This article followed all ethical standards for carrying out research without direct contact with human or animal subjects.

\section{Funding}

This research received no specific grant from any funding agency in the public, commercial, or not-for-profit sectors.

\section{Data availability statement}

Data sharing is not applicable to this article as no new data were created or analysed in this study.

\section{Disclaimer}

The views and opinions expressed in this article are those of the authors and do not necessarily reflect the official policy or position of any affiliated agency of the authors.

\section{References}

Adamo, D.T., 1989, 'Understanding the Genesis account in an African background', Caribbean Journal of Religious Studies 10(2), 17-25.

Adamo, D.T., 2001, Reading and interpreting the Bible in African indigenous churches, WIPF and Stock, Eugene, OR.

Adamo, D.T., 2010, 'The Deuteronomist(s)' interpretation of exilic suffering in an African Perspective', Old Testament Essays 3(1), 9-27.

Banana, S.C., 1990, The Gospel according to the ghetto, Mambo Press, Gweru.

Bennet, R.A., 1971, 'Black experience and the Bible', Theology Today 27, 422. https:// doi.org/10.1177/004057367102700406

Berlin, A., 2005, 'Psalms and the literature of exile: Psalms 137, 44, 69 and 78', in P.W. Flint \& P.D. Miller, Jr., (eds.), The book of Psalms: Composition and reception, pp. 65-86, Brill, Boston, MA.

Boland, R.J., 1985, 'Phenomenology: A preferred to research on information systems', in Research methods in information systems, pp. 193-201, North-Holland, Amsterdam.

Boyatzis, R.E., 1998, transforming qualitative information: Thematic analysis and code Development, Sage, Thousand Oaks, CA.

Braun, V. \& Clarke, V., 2006, 'Using thematic analysis in psychology', Qualitative Research in Psychology 32(2), 77-101. https://doi.org/10.1191/1478088706qp063oa

Bubner, R., 1975, 'Theory and practice in the light of the hermeneutic criticist controversy', Cultural Hermeneutics 2, 337-352. https://doi.org/10.1177/ 019145377500200408

Buckley, S.L., 2000, Teachings on usury in Judaism, Christianity and Islam, Edwin Mellen Press, Lewiston, ME.

Chitando, E., 2010, 'Equipped and ready to serve? Transforming theology and religious studies in Africa', Missionalia 38(2), 197-210.

Compagnon, D., 2011, A predictable tragedy: Robert Mugabe and the collapse of Zimbabwe, University of Pennsylvania Press, Philadelphia, PA.

Cone, J.H., 1985, For my people: Black theology and the black church, Skotaville, Johannesburg.

Cone, J.H., 1990, A black theology of liberation: Twentieth Anniversary Edition, Orbis, New York.

Dada, A.O., 2010, 'Repositioning contextual biblical hermeneutics in Africa towards holistic Empowerment', Black Theology: An International Journal 8(2), 160-174. https://doi.org/10.1558/blth.v8i2.160

Farnen, R.F., 1994, Nationalism, ethnicity, and identity: Cross-national and comparative perspectives, Transaction Publishers, New Brunswick.
Farisani, B.E., 2010, 'Black biblical hermeneutics and ideologically aware reading of texts', Scriptura 105, 507-518. https://doi.org/10.7833/105-0-169

Farisani, B.E., 2011, 'The Naboth vineyard story (1 Kings 21) and poverty eradication', in E.H. Scheffler \& W. Van Heerden (eds.), The Bible and the eradication of poverty: Biblical Studies - Old Testament (Tutorial Letter OTS2604/501/3/2011), pp. 61-72, University of South Africa, Pretoria.

Fisher, J., 1969, The Afrikaners, Cassell, London.

Foss, K., 2009, 'Jenny's call to help Zimbabwe answered', The Star 23 Jan., p6.

Goldingay, J., 2003, Introduction to the Old Testament: Israel's Gospel, Vol I, Intervarsity, Downers Grove, IL.

Gottwald, K.N., 1985, The Hebrew Bible. A socio-literary introduction to the Old Testament, Fortress, Philadelphia, PA.

Grabbe, L.L., 1992, Judaism from Cyrus to Hadrian, Vol. 1, The Persian and Greek periods, Fortress, Minneapolis, MN.

Guest, G.M. \& Namey, E.E., 2012, Applied thematic analysis, Sage, Thousand Oaks, CA.

Gutierrez, G., 1973, A theology of liberation: History, politics and salvation, Orbis, New York.

Hekman, S.J., 1986, Hermeneutics and the sociology of knowledge, University of Notre Dame Press, Notré Dame.

Holter, K., 2002, Old Testament research for Africa: A critical analysis and annotated bibliography of African Old Testament dissertations, 1967-2000, Peter Lang, New York.

Ibrahim, A.M., 2012, 'Thematic analysis: A critical review of its process and evaluation', West East Journal of Social Sciences 1(1), 39-47.

Javadi, M. \& Zarea, K., 2016, 'Understanding thematic analysis and its pitfall', Journa of Client Centre 1(1), 34-40. https://doi.org/10.15412/J.JCC.02010107

Kearney, R. 1996. 'Introduction', in R. Kearney (ed.), Paul Ricoeur: The hermeneutics of action, p. 1, Sage, London.

Kriger, N., 2003, Guerrilla veterans in the post-war Zimbabwe: Symbolic and violent politics, 1980-1987, Cambridge University Press, Cambridge.

Launderville, D., 1989, A comparative study of kingship in biblical Israel, homeric Greece, and Mesopotamia of the old Babylonian period, University of Microfilms International, Ann Arbor, MI.

Mapara, J., 2003, 'The Bible and literature: A case of biblical influence in some Shona novels', MA Diss., University of South Africa, Pretoria.

Maposa, R.S., Sibanda, F. \& Makahamadze, T., 2011, 'African theology and identity: Reflections on Zion Christian Church experiences and responses to the Zimbabwean crisis, 2000-2010', Missionalia 39(3), 248-267.

Maré, L.P., 2010, 'Psalm 137: Exile - not the time for singing the Lord Song', Old Testament Essays 23(1), 116-128.

Marks, D. \& Yardley, L., 2004, Research methods for clinical and health psychology, Sage, Thousand Oaks, CA.

Masenya (ngwana' Mphalele), M., 2004, How worthy is the woman of worth? Rereading Proverbs 31:10-31 in African-South Africa, Peter Lang, New York.

Masenya (ngwana' Mphalele), M., 2010, 'Parental instruction in differing contexts: Using hermeneutical phenomenology to understand selected biblical and African proverbs', Old Testament Essays 23(3), 728-751.

Mashayamombe, T., 2009, ZANU (PF) militias disrupt food donations in Mutare, Zimbabwe, viewed 09 January 2019, from http://www.zimeye.org/?p=10240.

Mendelson, J., 1979, 'Habermas-Gadamer debate', New German Critique18, 44-73. https://doi.org/10.2307/487850

Meredith, M., 2008, Mugabe: Power, plunder in the struggle for Zimbabwe, Jonathan Ball, Johannesburg.

Meyer, E.E., 2015, 'South African Old Testament criticism: Squeezing between an ancient text and contemporary context', HTS Theological Studies 71(3), 1-7. https://doi.org/10.4102/hts.v71i3.2876

Miller, J.M. \& Hayes, J.H., 1986, A history of ancient Israel and Judah, Westminster Press, Philadelphia, PA.

Moltmann, J., 1968, 'Towards a political hermeneutics of the Gospel', Union Seminary Quarterly Review 23, 303-323.

Muchemwa, M., 2009, ZANU (PF) food taskforce plunders grain, viewed 09 January 2019, from http://www.zimeye.org/?p=1599.

Mustaka, F., 2018, 'Zimbabwean generals deny troops shot and killed 6 protesters', The Daily Herald 13 November, 2018, viewed 18 January 2019, from https://www. dailyherald.com/article/20181113/news/311139940.

North, R., 1969, 'The Chronicler: 1-2 Chronicles, Ezra, Nehemiah', in Brown, Fitzmyer \& Murphy (eds.), pp. 402-438.

Nowell, L.S., Norris, J.M., White, D.E. and Moules, N.J., 2017, 'Thematic analysis: Striving to meet the trustworthiness criteria', International Journal of Qualitative Methods 16, 1-13. https://doi.org/10.1177/1609406917733847

Nuyen, A.T., 1995, 'Critique of ideology: Hermeneutics or critical theory?' Human Studies 17, 419-432. https://doi.org/10.1007/BF01343698

Resane, K.T., 2018, 'Biblical exegesis and hermeneutics of biblical texts: African approaches', Pharos Journal of Theology 99, 1-9.

Ricoeur, P., 1971, 'The model of the text: Meaningful action considered as a text', Social Sciences 38, 529-565. 
Ricoeur, P., 1974, The conflict of interpretation: Essays in interpretation, Northwestern University Press, Evanston, IL.

Ricoeur, P., 1981, Hermeneutics and the sciences, Cambridge University Press, Cambridge.

Roberge, J., 2008, Paul Ricoeur, in Culture et les sciences humaines, Presses de I' Université Lava, Québec.

Rugwiji, T., 2008, 'Reading the exodus tradition from a Zimbabwean perspective', MA Diss., University of South Africa, Pretoria.

Rugwiji, T., 2012, Reading the exodus liberation motif in the modern postbiblical world: The Zimbabwean society and the reality of oppression, LAP Lambert Academic, Saarbrücken.

Rugwiji, T., 2013, 'Appropriating Judean Postexilic literature in a postcolonial discourse: A case for Zimbabwe', PhD thesis, University of South Africa, Pretoria.

Rugwiji, T., 2014, 'Towards the quest for transforming Old Testament scholarship: The impact of political and socioeconomic crises on scholarship in Zimbabwe', Old Testament Essays 27/3, 1009-1034.

Rugwiji, T., 2017, 'Land, farming and socioeconomic development in Yehud: A ques for sustainable development towards poverty reduction in Zimbabwe', Scriptura 116/1, 1-34. https://doi.org/10.7833/116-1-1336

SAPA-DPA 2008, 'Zim blocks food relief charity', The Star, 05 June, p. 5.

Scheffler, E.H., 2001, Politics in ancient Israel, Biblia, Pretoria.

Scheffler, E., 2007, 'Criticising political power: The challenge of Deuteronomy 17:14-20', Old Testament Essays 20(3), 772-785.

Scheffler, E., 2013, 'Of poverty prevention in the Pentateuch as a continuing contemporary challenge', Verbum ET Ecclesia 34(2), Art. \#869, 14 pages. https:// doi.org/10.4102/ve.v34i2.869

Shaw, C.S., 1993, The speeches of Micah. A rhetorical-historical analysis, JSOT, Sheffield.

Smith, D.L., 1996, 'The politics of Ezra: Sociological indications of Judean society', in E.C. Carter \& L.C. Meyers (eds.), Community, identity and ideology: Social science approach to the Bible, 537-556, Eisenbrauns, Winona Lake.

Song, S.C., 1979, 'The black experience of the exodus', in G.S. Wilmore \& J.H. Cone (eds.), Black theology - documentary history (1966-1979), pp. 568-582, Orbis, Maryknoll, NY.
Spangenberg, I., 2006, 'The literature of the Persian period (539-333 BCE)', in W. Boshoff, E.H. Scheffler \& I. Spangenberg (eds.), Ancient Israelite literature in context, pp. 168-198, Protea, Pretoria.

Spangenberg, I., 2011, 'Reconciliation of different kind: The Christian religion and science', Paper read at OTANES research seminar, University of South Africa, Pretoria.

Strawn, B.A., 2009, 'Psalm 137', in R.E. Van Harn \& B.A. Strawn (eds.), Psalms for preaching and worship: A lectionary commentary, pp. 345-353, Eerdmans, Grand Rapids, MI.

Strydom, J.G. \& Wessels, W.J., 2000, Prophetic perspectives on power and justice, Biblia, Pretoria.

Suazo, R.S., 2008, 'Hermeneutics as approach: A way of understanding oneself in front of the text', Phavisminda Journal 7, 109-121.

Terry, S.M., 1983, Biblical hermeneutics, Zondervan Publishing House, Grand Rapids, $\mathrm{MI}$.

Tutu, D., 1978, 'Whither African theology', in E.W. Fasholé-Luke et al. (eds.), Christianity in independent Africa, p. 336, Rex Collins, London.

Upkong, S.J., 1994, 'Towards a renewed approach to enculturation theology', Journa of Inculturation Theology 1, 3-15.

Upkong, S.J., 2000, 'Developments in biblical interpretation in Africa: A historical and hermeneutical perspective', Journal of Theology for Southern Africa 108, 17.

Usue, E., 2007, 'Restoration or desperation in Ezra and Nehemiah? Implications for Africa', Old Testament Essays 20(3), 830-847.

Warmback, A.E., 2008, 'The journey continues: Oikotheology and urban ministry', Missionalia 36(2/3), 166-180.

West, G.O., 1991, Biblical hermeneutics of liberation modes of reading the Bible in the South African context, second edition, Orbis, Maryknoll, NY.

West, G.O., 1997, 'Finding a place among the posts for postcolonial criticism in biblical studies in South Africa', Old Testament Essays 10(2), 322-342.

Whittaker, M., 1984, Jews and Christians: Graeco-Roman views, Cambridge University Press, Cambridge.

Zimudzi, T.B., 2012, 'Book review. A predicable tragedy: Robert Mugabe and the collapse of Zimbabwe', Journal of Contemporary African Studies 30(3), 508-511. https://doi.org/10.1080/02589001.2012.701847 